\title{
RUNNERS AND RIDERS: THE HORSEMEAT SCANDAL, EU LAW AND \\ MULTILEVEL ENFORCEMENT
}

\author{
Catherine Barnard and Niall O’Connor*
}

Number of words in text: 11,394

Number of words in footnotes: 1,799

\begin{abstract}
The 2013 horsemeat scandal shone a bright light on some of the darkest corners of supply chain governance across the European Union, revealing a "blind spot" in current EU food law. "Beef" frozen food products were found to contain up to 100 per cent. horse. ${ }^{2}$ The British and Irish are squeamish about eating horse. Even for those countries where horsemeat is seen as a delicacy, the horse getting into the frozen "beef" was often of poor quality and possibly contaminated with "bute", a veterinary drug not permitted in food for human consumption. The ability of the EU's regulatory regime to prevent fraud on such a scale was shown to be hopelessly inadequate. EU food law, with its (over) emphasis on food safety, failed to prevent the occurrence of fraud and may even have played an (unintentional) role in facilitating or enhancing it. Domestic law offered little better protection thus showing the difficulties associated with the implementation of a multi-level and indeed multi-agency regulatory regime. Beyond the regulatory system, the EU's core Treaty commitment to the free movement of goods may also have laid the ground for complex and opaque supply chains into which unscrupulous traders and middlemen could slip unnoticed.
\end{abstract}

\footnotetext{
* Professor of EU Law and Employment Law, Trinity College, Cambridge and PhD Candidate in Law, Girton College, Cambridge. We should like to thank Milorad Radakovic, Clive Lewis, David Heald, Caoimhín MacMaoláin, Paul Davis, Steve Werner, Stuart Lendrum, Rod Ainsworth and the anonymous reviewers for their advice, as well as the participants at the seminars in Dubrovnik PhD programme in April 2015, the Centre for European Legal Studies, Cambridge in January 2016 and Glasgow Law School in March 2016.

${ }^{1}$ S. van der Muelen and others, "Fighting Food Fraud, Horsemeat Scandal; Use of Recalls in Enforcement throughout the EU" (2015) 10 European Food \& Feed Law Review 1, 2.

${ }^{2}$ F. Lawrence, "Horsemeat scandal: the essential guide" The Guardian 15 February 2013.
} 


\section{KEYWORDS}

Horsemeat Scandal, EU Law, Free Movement of Goods, Multilevel Enforcement, Food Safety

\section{INTRODUCTION}

The concept of free movement of goods supports a stable supply chain based on price, availability and quality. The daily experience of food shopping reveals the extent to which consumers across the EU enjoy goods from other Member States: Italian pasta, French cheese, Spanish wine and British chocolate. Undoubtedly, there has been a struggle to get some of these products onto the markets of other Member States. This fight is illustrated by well-known cases such as Cassis de Dijon, ${ }^{3}$ Beer Purity, ${ }^{4}$ and Italian Chocolate. ${ }^{5}$ These cases are but part of the history of market integration in the EU. The reality today is that millions of food products are traded between Member States each year without importers going near a court, let alone the Court of Justice of the European Union (CJEU). Since the system appeared to be working, the question, then, is how did horsemeat get into the food chain and why did the EU's food safety regime, premised on the idea of the "free movement of safe and wholesome food", 6 fail to detect it? Did the EU regulatory regime and rules on free movement of goods actually exacerbate the problem? Speaking at the height of the scandal, the then EU Health Commissioner, Tonio Borg said:

[t]he freedom of movement of goods within the European Union is something so positive that I would consider it today to be the cornerstone of the entire [EU] in the same way that the freedom of movement of services, of capital and of persons is (...) The main problem is fraudulent labelling. ${ }^{7}$

His remarks encapsulate the well-rehearsed assessment by the EU of the causes of the horsemeat scandal, with the emphasis-perhaps unsurprisingly-placed on the perpetrators of the fraud as the wrongdoers. Any potential role played by EU law is roundly dismissed.

\footnotetext{
${ }^{3}$ Case C-120/78 Rewe Zentrale v Bundesmonopolverwaltung für Branntwein [1979] ECR 649.

${ }^{4}$ Case C-178/84 Commission v Germany [1987] ECR 1227.

${ }^{5}$ Case C-14/00 Commission v Italy [2003] ECR I-513.

${ }^{6}$ Council and Parliament Regulation (EC) No 178/2002 (OJ 2002 L 31 p. 1).

${ }^{7}$ Press conference by Tonio Borg on findings of horsemeat in meat products containing different type of meat Brussels 13 February 2013.
} 
This article will seek to challenge this deceptively simple assessment of the genesis of the scandal.

We shall argue that the EU Food Regulation was premised on an assumption that all traders would act responsibly and would want the best for their customers. The fraud on the scale that occurred, facilitated by lengthy supply chains and inadequate checks on the quality of products coming into Member States, was not on the radar of the legislators at either EU or national level. Paradoxically, a misplaced trust in EU food law may have further served to exacerbate the problem. We shall also argue that the revised regime, introduced after the crisis, goes only some way towards addressing the scandal. It seems as if, to use a particularly apposite metaphor, the stable door has been (partially) closed but only after the horse has well and truly bolted.

We believe an understanding of what happened in the horsemeat scandal is important for three reasons. First, food fraud is an ongoing issue of high public policy relevance. In the wake of several recent food scares, food safety is no longer viewed as merely a scientific matter but rather a highly political and politicised issue. ${ }^{8}$ Second, the scandal highlights the problems with a multilevel regime in which EU rules rely heavily on national enforcement. Third, even following Brexit, EU rules will continue to have a significant role to play in regulating the production of processed foods in the UK, not to mention in the rest of the EU/EEA. An understanding of what went wrong in the horsemeat scandal remains important. We therefore examined the relevant legal framework, together with contemporary evidence (largely newspaper sources). We supplemented the documentary evidence with interviews, some of which cannot be reported directly. However, we used these interviews as a means of testing the accounts contained in the documentary evidence.

The article is structured as follows. It begins by looking at the EU regulatory regime for food safety (Section I). It then considers how the horsemeat crisis developed (Section II), the causes of the scandal (Section III) and what has happened since, including the EU's legislative response (Section IV).

\section{THE EU'S FOOD SAFETY REGIME}

\footnotetext{
${ }^{8}$ T. Knowles, R. Moody and M. G. McEachern, "European Food Scares and Their Impact on EU Food Policy" (2007) 109 British Food Journal 43, 56.
} 


\section{A. The Treaty}

As MacMaoláin has put it, 'it is difficult to understate the impact that EU rules (...) have on [Member State] food law'. ${ }^{9}$ Some of those rules are very familiar: Article 34 of the Treaty on the Functioning of the European Union (TFEU) provides for the free movement of goods within the Internal Market. Since the establishment of the principle of mutual recognition in Cassis de Dijon, producers whose goods have been lawfully produced in one Member State can in principle be sold in another without restriction. ${ }^{10}$ There appear, however, to be difficulties in the practical application of the principle of mutual recognition. In the first instance, the principle requires trust between market operators but, with more than 30 years of its operation, it has also created (blind) trust between traders, middlemen and consumers. ${ }^{11}$ This trust in the mutual recognition principle held by economic operators is also largely held by the Member State authorities, who are also well-used to watching a free flow of goods from other Member States, suppliers and middlemen. This trust is not extended towards the administrative authorities of other Member States. It has in fact been suggested that this mistrust "may even be reinforced by dialogue between national administrations that is far from fluent (...) national administrations tend to fall back on a national administration's framework, which is often characterized by unpredictable decisions (...) excessive formalism, delays, procedural costs, lack of transparency, and difficulties in applying the principle of mutual recognition". ${ }^{12}$ In other words, the EU's internal market is much more effectively integrated from the perspective of economic operators exploiting free movement than it is from the perspective of administrative agencies charged with applying the rules regulating the market.

States can of course prevent the import of foods from other Member States on health grounds under Article 36 TFEU. The protection of human health is one of the most frequently invoked derogations to the EU's free movement rules, with the CJEU recognising that the "health and life of humans rank foremost among the property interests protected by Article

\footnotetext{
${ }^{9}$ C. MacMaoláin, Food Law (Oxford 2015), 13.

${ }^{10}$ Case C-120/78 Rewe Zentrale v Bundesmonopolverwaltung für Branntwein [1979] ECR 649.

${ }^{11}$ For an example of this, see the interview with Martin McAdam whose meat, which he had sourced from two separate Polish factories had tested positive as horsemeat BBC News 8 February 2013.

${ }^{12}$ C. Janssens, The Principle of Mutual Recognition in EU Law (Oxford 2013), 108-09.
} 
[36]". ${ }^{13}$ However, the Court's case law has shown that it is wary of its use by the Member States to disguise restrictions on trade. ${ }^{14}$

Another potential justification for restricting trade in food is the consumer protection "mandatory requirement". ${ }^{15}$ As MacMaoláin notes, however, "a ban on the sale of a foodstuff on health grounds more readily satisfies the proportionality test than one based on consumer protection". ${ }^{16}$ Given the reluctance of the CJEU to embrace the human health derogation, it is therefore unlikely that a consumer protection argument will succeed. Indeed, the case law shows that it is difficult for the Member States to demonstrate that a prohibition based on consumer protection is a proportionate response. ${ }^{17}$

\section{B. The General Food Regulation}

This reluctance by the Court to accept the public health argument, combined with the threat of a damages claim, has made the Member States cautious about raising these arguments to obstruct free movement of foodstuffs. EU secondary legislation has stepped in to fill the gaps left in the protection of human health. Indeed, this is an area which has now become heavily regulated, with a number of measures adopted under Article 114 TFEU on the completion of the Internal Market. Taken as a whole, these measures are intended to promote an EU integrated approach to food safety which aims to ensure "a high level of food safety, animal health, animal welfare and plant health within the European Union through coherent farm-totable measures and adequate monitoring, while ensuring the effective functioning of the internal market". 18

The most important piece of legislation in force at the time of the horsemeat scandal was the General Food Law Regulation 178/2002 which had been adopted in the wake of the BSE crisis. ${ }^{19}$ This Regulation lays down the general principles and requirements of EU food law, establishes the European Food Safety Authority (EFSA) and sets out procedures in matters of food safety. The aims of the Regulation are set out in Article 1: "[t]his Regulation

\footnotetext{
${ }^{13}$ Case C-320/93 Lucien Ortscheit GmbH v Eurim-Pharm Arzneimittel GmbH [1994] ECR I-5243, at para. 16.

${ }^{14}$ C. Barnard, The Substantive Law of the EU: The Four Freedoms (Oxford 2012), 158.

${ }^{15}$ Case C-120/78 Rewe Zentrale v Bundesmonopolverwaltung für Branntwein [1979] ECR 649.

${ }^{16}$ MacMaoláin, Food Law, p. 88.

${ }^{17}$ Case C-120/78 Rewe Zentrale v Bundesmonopolverwaltung für Branntwein [1979] ECR 649.

${ }^{18}$ See European Commission Food Safety Overview < http://ec.europa.eu/food/ > accessed 20 May 2016.

${ }^{19}$ Council and Parliament Regulation (EC) No 178/2002 (OJ 2002 L 31 p. 1).
} 
provides the basis for the assurance of a high level of protection of human health and consumers' interests in relation to food, taking into account in particular the diversity in the supply of food including traditional products, whilst ensuring the effective functioning of the internal market". The Regulation also sets out the principles upon which EU food law is based. Article 5 lays down the general objective of food law: "to ensure a high level of protection of human life and health and/or the protection of consumers' interests, including fair practices in food trade, taking account of for example the protection of animal health and welfare, the achievement of free movement; and taking into account international standards". 20

The principles of food safety are then outlined. The first principle concerns risk analysis: there must be objective, evidence-based, and independent risk assessment ${ }^{21}$ with a risk management strategy which takes account of the results of the risk assessment, EFSA opinions and the precautionary principle. ${ }^{22}$ This is combined with the principle of transparency and communication to the public. ${ }^{23}$ The next principle involves transparency more generally, in particular through public consultation during the preparation, evaluation and revision of food law, except in cases of urgency. ${ }^{24}$ The final principle of EU food law, and most important for our purposes, is the protection of consumer interests. The aim is to allow consumers to make informed choices through the prevention of fraudulent or deceptive practices, the adulteration of food and any other practices which may mislead the consumer.

The Regulation makes clear that the primary obligation to deliver on these principles lies with the food trade. It must ensure that the food is $\mathrm{safe}^{25}$ at all stages of production, processing and distribution, within the businesses under its control and it must verify that such requirements are met. ${ }^{26}$ Of particular relevance for the horsemeat crisis is Article 19. Article 19(1) provides that, should operators believe that food is not in compliance with EU food safety requirements, they must immediately initiate procedures to withdraw the food from the market and inform the competent authorities. Where the product may have reached the consumer, the operator must effectively and accurately inform the consumers of the

\footnotetext{
${ }^{20}$ Ibid., at art 5.

${ }^{21}$ Ibid., at art 6(2).

${ }^{22}$ Ibid., at arts 6(3) and 7.

${ }^{23}$ Ibid., at art 10

${ }^{24}$ Ibid., at art 9.

${ }^{25}$ Ibid., at art 14 provides that unsafe food is that which is injurious to health or unfit for human consumption.

${ }^{26}$ Ibid., at art 17(1).
} 
reason for its withdrawal, and if necessary, recall from consumers, products already supplied to them when other measures are not sufficient to achieve a high level of health protection. Similar obligations apply to retailers and distributors under Article 19(2). They must also initiate procedures to withdraw from the market, products not in compliance with the food safety requirements and must pass on all relevant information necessary to trace food. This process is assisted through the rules on traceability. Food business operators (FBOs) must ensure the traceability of the food at all stages of production, processing and labelling. ${ }^{27}$ Food must also be adequately labelled or identified to facilitate its traceability and accompanied by a delivery note. ${ }^{28}$ Finally, it is the Member States which must enforce food law and monitor and verify that the relevant requirements of food law are fulfilled by FBOs at all stages of production, processing and distribution. The issue of enforcement raises interesting questions about the division of competences between the various regulatory bodies. This will be discussed further below.

In addition to setting out the objectives of food law and the responsibilities of operators the General Food Regulation makes provision for a rapid alert system for food and feed (RASFF). This system, which was first established in 1979, provides that when a Member State has any information about a serious health risk deriving from food or feed, it must immediately notify the European Commission. ${ }^{29}$ In particular, RASFF members must notify the Commission when measures such as the withdrawal or recall of food are taken in order to protect consumer health and if rapid action is required. Members must also notify the Commission if they have concluded, in consultation with operators that food or feed should not be placed on the market if that measure is taken on account of a serious risk. The same applies when the product in question is placed on the market under conditions. The Regulation gives the Commission the power to take emergency measures if the risk cannot be satisfactorily contained by the Member States. ${ }^{30}$ Generally, the Commission is assisted by the comitology committee, the Standing Committee on the Food Chain and Animal Health, composed of representatives of the Member States. ${ }^{31}$

\footnotetext{
${ }^{27}$ Ibid., at art 18 .

${ }^{28}$ Ibid., at art 18(4).

${ }^{29}$ Ibid., at art 50. See also Commission Regulation No 16/2011 (OJ 2011 L 6 p.7) and $<$ http://ec.europa.eu/food/food/rapidalert/index_en.htm. > accessed 20 May 2016.

${ }^{30}$ Ibid., at art 53(1).

${ }^{31}$ Subsequently renamed the Standing Committee on Plants, Animals, Food and Feed.
} 
Finally, the Regulation provides for the creation of EFSA. ${ }^{32}$ EFSA is an independent body which provides scientific advice and communication on existing and emerging risks, in close collaboration with the Member States and in consultation with stakeholders. Its role is as risk assessor. It provides scientific advice in order to enable the EU's regulatory Authorities to take effective risk management decisions. ${ }^{33}$ One of the major difficulties faced by EFSA in its assessment is the wide thematic scope for the identification of emerging risks. Lawless points to several factors which have been highlighted by the Stakeholders' Consultative Group on Emerging Risks. Such factors include social and economic developments-notably pressure for costs reduction, changes in human lifestyle or diet-such as new foods and food preparations and analytical developments including the detection of new low levels of contaminants which cannot be adequately risk assessed. Finally, and most significantly for our purposes, he identifies changes in the operation and functioning of the food chain, notably more globalised and longer transportation chains, different regulatory controls and standards and issues of food security. ${ }^{34}$

\section{Other Relevant Secondary Legislation}

In addition to the General Food Regulation, there are a number of other pieces of EU secondary legislation which came into play during the horsemeat scandal, notably Regulation $882 / 2004$ on official controls performed to ensure the verification of compliance with EU food law. This Regulation gives the Commission the power to recommend coordinated plans to establish the prevalence of hazards in feed, food or animals. ${ }^{35}$ Regulation 853/2004 makes provision for specific hygiene rules for food of animal origin. It provides for additional labelling requirements applicable to specific foods, including food originating from hoofed animals. $^{36}$

Complementary to this is Regulation 854/2004 which contains specific rules for the organisation of official controls on products of animal origin intended for human

\footnotetext{
${ }^{32}$ Council and Parliament Regulation (EC) No 178/2002 (OJ 2002 L 31 p. 1).

${ }^{33}$ See "About EFSA" < http://www.efsa.europa.eu/en/aboutefsa> accessed 20 May 2016. See also more generally, A Alemanno and S Gabbi (eds), Foundations of EU food law and policy: ten years of the EFSA (Farnham 2014).

${ }^{34}$ J. Lawless, "EFSA under Pressure: Emerging Risks, Emergencies and Crises" in A. Alemanno and S. Gabbi (eds), Foundations of EU Food Law and Policy (Farnham 2014), 93, 102.

${ }^{35}$ Council and Parliament Regulation (EC) No 882/2004 (OJ 2004 L165 p. 1).

${ }^{36}$ Council and Parliament Regulation (EC) No 853/2004 (OJ 2004 L 139 p. 55).
} 
consumption. ${ }^{37}$ It requires the official veterinarian to perform auditing and inspection tasks, including checking and analysing relevant information from the records of the holding of the provenance of animals intended for slaughter, including food chain information. EU legislation also provides for labelling requirements for food products. ${ }^{38}$

In addition, there are a number of regulations dealing specifically with the health and movement of horses. Regulation 37/2010 on pharmacologically active substances identifies Phenylbutazone (bute) as a veterinary drug, commonly used a painkiller in horses and whose use is allowed only in non-food producing animals. ${ }^{39}$ Regulation 504/2008 contains the rules on the identification of horses and the measures taken to prevent meat from unidentified horses entering the food chain. ${ }^{40}$ There is also an obligation in the Regulation for Member States to increase the level of controls where there are indications of possible noncompliance. This volume of legislation certainly looks good on the books but did it work in practice?

\section{THE GENESIS OF THE SCANDAL}

\section{A. The Domestic Level}

On 14 January 2013, the then Irish Minister for Agriculture, Simon Coveney, was informed by the Food Safety Authority of Ireland (FSAI) that it had found 29 percent horse DNA in a single beef burger manufactured by Silvercrest and sold in Tesco. This finding sparked an investigation that would soon implicate manufacturers, retailers, middlemen and regulators across the entire EU. As the Irish report into the scandal sought to emphasise, "what had been uncovered was a pan-European problem of fraudulent mislabelling of certain beef products. Almost all Member States have been affected by the problem". ${ }^{41}$ The following day, the FSAI published the full findings of its targeted study under its food fraud programme, examining the authenticity and labelling accuracy of a number of burger products.

\footnotetext{
${ }^{37}$ Council and Parliament Regulation (EC) No 854/2004 (OJ 2004 L 139 p. 206).

${ }^{38}$ Council and Parliament Directive 2000/13/EC (OJ 2000 L 109 p. 29 and Council Directive 90/496/EEC (OJ 1990 OJ L 276 p. 40) since replaced by Regulation 1169/2011 discussed in detail below.

${ }^{39}$ Commission Regulation (EU) No 37/2010 (OJ 2010 L 15 p. 1).

${ }^{40}$ Commission Regulation (EC) No 504/2008 (OJ 2008 L 149 p. 3).

${ }^{41}$ Department of Agriculture Report on the Investigation into Equine DNA and the Mislabelling of Processed Beef 14 March $2013<$ www.agriculture.gov.ie> accessed 20 May 2016.
} 
The FSAI used advance testing methods which had not been routinely used before. ${ }^{42}$ The survey consisted of the sampling of meat at retail level using DNA-based analytical techniques to differentiate between animal species. ${ }^{43}$ The results showed that some of the products labelled as beef actually contained horse and pig DNA. Of the 27 beef products tested, 37 per cent. were found to contain horsemeat and 85 per cent. contained pig meat. In the majority of the samples taken, apart from the Tesco beef burger, with 29 per cent. horse, horse DNA was found at very low levels. ${ }^{44}$ The Irish investigation concluded that the equine DNA found in the consignments of frozen beef products (beef trimmings) was labelled as originating from an EU-approved plant in Poland. This product had been used as a raw material in the burgers produced by Silvercrest Meats. ${ }^{45}$ This material had arrived at the company through traders in both Ireland and the UK. Additional testing at Silvercrest found horsemeat in Polish labelled ingredients ranging from 4.1 per cent. to 37.8 per cent. The Report found that there was no evidence that Silvercrest had deliberately passed off horsemeat as beef but the company was criticised for not respecting customer specifications as to approved suppliers. Silvercrest was not, however, alone and the initial Irish investigation subsequently implicated a number of additional companies.

Particular concern was expressed about the activities of traders and intermediaries. ${ }^{46}$ One such trader, McAdam Food Products was found to have stored beef contaminated with both Irish and Polish horsemeat at a cold store in Northern Ireland. This was one of two consignments of beef from McAdam which had been rejected by Rangeland Meats. The second consignment was subsequently collected on behalf of a UK trader and was destined for the Netherlands. Rangeland Meats itself notified the Irish Authorities on 31 January 2013 that it had found horse DNA in a consignment of Polish-labelled meat ingredients imported through McAdam Food Products from a UK trader. Subsequent tests found the trimmings to include up to 75 per cent. horse. ${ }^{47}$

A particularly pernicious example of contamination was found at QK Meats. The company informed the Department of Agriculture on 5 February 2013 that it had imported consignments of Polish-labelled beef trimmings which contained horsemeat. These products had been sourced from 19 different Polish suppliers over a continuous period. Having

\footnotetext{
${ }^{42}$ Ibid., at p. 9.

${ }^{43}$ Ibid.

44 Ibid.

${ }^{45}$ Ibid., at p. 10

${ }^{46}$ Ibid., at p. 4.

${ }^{47}$ Ibid., at p. 17.
} 
conducted its own testing as early as 27 June 2012, the company found that a number of products contained horse DNA. The company failed to inform the Irish Authorities of these positive results. Instead, they simply contacted the Polish supplier and had them take back the consignment. The company continued to source its products from the same suppliers even after the contamination had been found. ${ }^{48}$ Another company, B\&F Meats was found to have dispatched horse meat to a single customer in the Czech Republic via a UK trader using a Czech label which referred to "beef". 49

The Irish Authorities not only participated in the EU follow up action (considered below) but it also held meetings with industry representatives and agreed a protocol for a more wide-ranging testing of beef products for adulteration. It was decided to test a number of food categories, namely pre-packaged beef products offered to consumers or caterers, nonpre-packaged beef products offered to consumers or caterers, and finally meat ingredients used in processed beef products. ${ }^{50}$ The first set of results which were published in March 2013 showed that the majority of the 957 products tested-apart from those already found to be positive-did not contain horsemeat. As to the type of meat which had been adulterated, the Irish Report concluded that it concerned mainly "manufacturing beef product", that is to say beef used for further processing, such as frozen or manufactured beef products including burgers and minced meat. ${ }^{51}$ The type of products involved made the task of the regulatory authorities all the more complicated and may have played a significant role in facilitating the adulteration. As the Irish Report remarks, "multiple ingredients from some 40 suppliers (many supplying a variety of raw ingredient products) were used in production batches and the mixture of ingredients could vary in every half hour production batch". 52

The Irish investigation was followed by an inquiry in the UK conducted by the Food Standards Agency (FSA). In early February 2013, the FSA announced that it had tested a quantity of frozen meat on the premises of Freeza Meats in Northern Ireland. Of the 12 samples tested from the suspect consignment, two came back positive for horsemeat at around 80 per cent. At the same time, Findus, a frozen food company informed the FSA that it had found horsemeat in frozen lasagne products. The lasagne had been produced in Luxembourg by the French company Comigel, with meat supplied by Spanghero, another

\footnotetext{
${ }^{48}$ Ibid., at p. 18.

${ }^{49}$ Ibid., at p. 21.

${ }^{50}$ Ibid., at p. 5.

${ }^{51}$ Ibid., at p. 8.

${ }^{52}$ Ibid., at p. 10.
} 
French company. The FSA subsequently confirmed that the meat content of beef lasagne products previously recalled by Findus had tested positive for more than 60 per cent. horsemeat. ${ }^{53}$ It was at this point that the UK notified the Commission. The Commission's response is dealt with in the next section. The frozen meat found to contain horse originated in Romania and was bought through middlemen based in Cyprus and the Netherlands. The Luxembourg Authorities concluded that the contaminated batches distributed in the UK could be traced back to a consignment of "bovine" meat delivered by Spanghero in Castlenaudary in the South of France. ${ }^{54}$ Concern was also being raised about whether bute, a veterinary product used in animals not intended for the food market, had entered the food chain.

As in Ireland, there was more than one UK supermarket caught up in the scandal. On 8 February 2013, Aldi withdrew two beef products supplied by Comigel after its own tests confirmed the presence of horsemeat. Asda and Tesco also withdrew products from the same suppliers on a precautionary basis. Tesco subsequently discovered that some of its frozen Everyday Value Spaghetti Bolognese, which had been previously withdrawn, had significant levels of horse DNA, exceeding 60 per cent. ${ }^{55}$ In March 2013, Lancashire County Council informed the FSA that it had identified 100kg of horsemeat imported from Hungary labelled as beef. ${ }^{56}$ Subsequently, low levels of bute were found in $340 \mathrm{~g}$ tins of Asda Smart Price Corned Beef. ${ }^{57}$ By June 2013, the FSA confirmed it had received a further 19,050 industry results from testing beef products for horse DNA. ${ }^{58}$ The Agency also published the full report of the local authority testing programme. The new results showed that three beef products contained horse DNA at or above the 1 per cent. threshold but all tests were negative for bute.

\section{B. The EU Level}

\footnotetext{
${ }^{53}$ See FSA, "Findus beef lasagne products found with horsemeat" <http://webarchive.nationalarchives.gov.uk/20150624093026/http://food.gov.uk/newsupdates/news/2013/5514/findus> accessed 23 March 2016.

${ }^{54}$ For a full map of the trade in horsemeat see

$<$ www.theguardian.com/uk/datablog/interactive/2013/feb/15/europe-trade-horsemeat-map-interactive > accessed 23 March 2016.

${ }^{55}$ See FSA, "Tesco finds horsemeat in some Everyday Value Spaghetti Bolognese product" $<$ http://webarchive.nationalarchives.gov.uk/20150624093026/http://food.gov.uk/newsupdates/news/2013/5529/tesco-bolognese> accessed 23 March 2016.

${ }^{56}$ See FSA, "Hungarian horsemeat labelled as beef"

$<$ http://webarchive.nationalarchives.gov.uk/20150624093026/http://food.gov.uk/newsupdates/news/2013/5604/hungary> accessed 23 March 2016.

${ }^{57}$ See FSA, "Very low levels of bute found in Asda Smart Price Corned Beef" <http://webarchive.nationalarchives.gov.uk/20150624093026/http://food.gov.uk/newsupdates/news/2013/5623/asda-bute> accessed 23 March 2016.

${ }^{58}$ See FSA, "More results of beef product testing published" <http://webarchive.nationalarchives.gov.uk/20150624093026/http://food.gov.uk/newsupdates/news/2013/5694/beef-product-testing> accessed 23 March 2016.
} 
The UK informed the Commission on 8 February 2013 that Findus UK had been selling beef lasagne supplied by a French company, Comigel, which tests showed contained between 80 and 100 per cent. horsemeat. On 13 February 2013, the Irish presidency of the Council organised an informal ministerial meeting between the Commission and the ministers from the Member States most affected by the crisis, namely France, Luxembourg, Sweden, Romania, Poland, the UK and Ireland. As a result of this meeting, the Commission proposed an intensive coordinated monitoring plan to check for horse DNA in beef products and bute in horse carcases. ${ }^{59}$ This was followed by discussions between the Commission and Member State experts during an extraordinary meeting of the Standing Committee of the Food Chain and Animal Health. The Member States agreed to a programme of testing which would last for a period of one month in order to identify the extent of the fraud at issue.

The testing programme commenced on 1 March 2013 with a threshold of 1 per cent. equine content being established. The results of these tests were published in April 2013 and formed the basis of the EU's consideration of future actions. 7,259 tests were carried out by the competent authorities in the then 27 Member States, of which 4,144 were tested for the presence of horse DNA and 3,115 were tested for the presence of bute. Of those tests, 193 revealed positive traces of undeclared horse DNA (4.6 per cent.) and 16 showed positive traces of bute $\left(0.51\right.$ per cent.). ${ }^{60}$ By mid-April, a joint assessment from EFSA and the European Medicines Agency (EMA) concluded that the illegal presence of residues of bute in horsemeat was of low concern due to the unlikelihood of exposure or toxic effects. A second round of testing was conducted one year later in April 2014 following a fresh Commission Recommendation. ${ }^{61}$ 2,622 tests were carried out in the now 28 Member States, as well as in Norway, Iceland and Switzerland, to detect traces of horse DNA in beef products. Bute testing was not repeated in 2014, due to the low level of samples that tested positive for residues in 2013. The results, which were published in July 2014, showed that only 16 of the 2,622 samples were found to contain horsemeat. ${ }^{62}$

\footnotetext{
${ }^{59}$ Commission Recommendation 2013/99/EU (OJ 2013 L 48 p. 28).

${ }^{60}$ See Outcome of the coordinated control plan with a view to establish the prevalence of fraudulent practices in the marketing of certain foods 2013 $<$ http://ec.europa.eu/food/food/horsemeat/docs/results_competent_authorities_2013_en.pdf> accessed 23 March 2016.

${ }^{61}$ Commission Recommendation 2014/180/EU (OJ 2014 L 95 p. 64).

${ }^{62}$ See Outcome of the coordinated control plan with a view to establish the prevalence of fraudulent practices in the marketing of certain foods 2014
} 


\section{WHAT WENT WRONG?}

So why then did the EU's regulatory system fail and why did horsemeat, some of it contaminated, get into the food chain? It appears that a number of factors, at both a domestic and EU level, coalesced to help create the crisis. This section will deal with these factors in turn.

\section{A. The Domestic Level}

In the case of the UK, the first cause of the crisis was the unsatisfactory division of competences between the regulators. Concern was expressed in both the written and oral evidence presented to the UK House of Commons Environment Select Committee about the fragmented nature of the UK Government bodies with responsibility in this field. According to the consumer organisation Which?, "food issues in practice do not break down into the simple delineations that are made between government departments". ${ }^{63}$ This fragmentation largely resulted from the Machinery of Government changes which had been introduced by the coalition Government in July 2010. As a result of these changes, the FSA is exclusively responsible for food safety in England, although it has delegated enforcement responsibilities to the local authorities. However, it no longer holds responsibility for food composition, origin labelling and authenticity which were moved to the Environment Department (Defra). To add to the confusion, Defra is responsible for food composition policy but has delegated enforcement to the FSA. According to Lord Rooker, CEO of the FSA, labelling is "not really for us, because it is not a food safety issue". ${ }^{64}$ This approach also goes against the increasing recognition that "the best outcomes are guaranteed not by having animal health officers focus only on animal production, environmental experts only on environmental contamination, and public health officers only on food hygiene. Rather, organizations and governments are recognizing that integration and collaboration are key to an effective food chain approach". ${ }^{65}$ The UK Environment Select Committee concluded that "the FSA's diminished role has led to a lack of clarity about where responsibility lies, and this has weakened the UK's ability to

\footnotetext{
$<$ http://ec.europa.eu/food/food/horsemeat/docs/results_competent_authorities_2014_en.pdf> accessed 23 March 2016.

${ }^{63}$ Environment, Food and Rural Affairs Committee - Eighth Report on Contamination of Beef Products 14 February 2013, at para. 17.

${ }^{64}$ Ibid., at para 18. In Ireland, on the other hand, labelling issues are more integral to the work of the FSAI see $<$ www.fsai.ie > accessed 20 April 2016.

${ }^{65}$ J. Vapnek, "Legislative Implementation of the Food Chain Approach" (2007) 40 Vanderbilt Journal of Transnational Law 987, 995.
} 
identify and respond to food standards concerns. Furthermore, the current contamination crisis has caught the FSA and Government flat-footed and unable to respond effectively within structures designed primarily to respond to threats to human health". 66

The second factor was that there had been awareness in industry circles that adulteration was taking place long before the scandal unfolded but, at least in the case of QK Cold Meats, they had not taken action. This Irish company had been testing for equine DNA for some time and had found positive results without informing the appropriate authorities. Further bad practice among suppliers was evident, with, as already mentioned, the Irish Report finding that certain companies had disrespected customer specifications only to use approved suppliers. This was the case with Silvercrest, whose parent company, ABP was found to have failed to maintain proper oversight of its subsidiary. According to Tim Smith, Technical Director of Tesco, it was the suppliers and not the retailers who deviated from approved supply chains: "the fact is that Silvercrest, for whatever reason, chose to use suppliers that we had not approved and audited (...) If somebody chooses to step outside that process deliberately, for whatever commercial reason, then it is impossible to check a supplier in Poland, which we do not even know exists". 67

It was not just failings at company level. There is anecdotal evidence that fraudulent practices had been going on at a local level for some time, with a number of unofficial abattoirs passing on horse, sheep and pig meat to producers. The financial incentive for fraud has always been high given that horsemeat is much cheaper to obtain. The issue had already arisen in respect of Mexican horses being imported into the EU after the US imposed a ban on horse slaughtering. Imports to the EU of horsemeat from Mexico jumped from EUR 1.3 million in 2006 to EUR 11.8 million in 2007, peaking at EUR 21.4 million in 2010. Owen Patterson, the former UK Environment Secretary expressed concerns that the Mexican horsemeat was being passed off as beef once it entered the EU market: "[o]nce the horse meat is through customs and inside the single market, much of it is being passed off as beef". ${ }^{68}$ As the Irish Report noted, companies could purchase the raw material from Poland at EUR 400 per tonne less than the price of corresponding beef trimmings available in Ireland.

\footnotetext{
${ }^{66}$ Ibid., at para. 19.

${ }^{67}$ Ibid., at para. 11.

${ }^{68}$ J. Forsyth, "The horsemeat scandal shows the true extent of Europe's power in Britain" The Spectator 16 February 2013.
} 
Not only was there the financial incentive to commit fraud, but there was also economic pressure being placed on retailers. Indeed, competitive supermarket pricing can be said to be a primary motivator in utilising imported materials in the manufacturing process. The UK National Farmers Union highlighted their concern that the "integrity of beef products has been compromised by using cheaper imported sources of meat". ${ }^{69}$ Supply chains and costs are both linked to the type of meat involved. The British Meat Processors Association suggested that "modern food supply chains can be complex, with many handoffs, particularly in the case of more highly processed products, and raw materials, ingredients and final products are increasingly traded internationally". ${ }^{70}$ Economy beef burgers sold in the UK need only contain 47 per cent. beef, which itself may also contain added bovine collagen and fat. Permitted ingredients include water, additional protein (filler), additives and seasonings. ${ }^{71}$ Although the supermarkets in their evidence before the UK Select Committee emphasised that their safety checks are not influenced by the type of meat involved, it seems apparent that cheaper processed meat is much more easily adulterated.

The third factor as concluded by the UK's Environment Select Committee, in its initial Report delivered in the immediate aftermath of the scandal, was that the current arrangements for testing and control across the European food industry have failed UK consumers. Member State regulatory authorities were simply not looking for horsemeat as it was not on their radar. The FSA confirmed that it tests on a risk assessment basis. Horsemeat was not considered a large adulteration risk and so it was not being tested for. In addition, cuts to local authority budgets in the UK have also had an impact. The scale of the task placed on national regulators is all the more challenging in that domestic regulation has to deal with the inter-EU scale of the trade. In its recent Report, tracking enforcement activity over the past five years, the FSA confirmed that many councils are failing to meet their obligations. ${ }^{72}$ In fact, in this five year period-which includes the horsemeat scandal—-the number of tests for adulteration or mislabelling had actually fallen by six per cent. Of particular concern is the drop in the random sampling of food. The decline in interventions may be attributed in part to a 17 per cent. fall in the number of environmental health inspectors since 2010 . In a letter to George Osborne, a number of leading food safety experts have noted that since the horsemeat crisis, far from supporting further testing, the Government has required the FSA to make

\footnotetext{
${ }^{69}$ Environment, Food and Rural Affairs Committee - Eighth Report on Contamination of Beef Products, at para. 6.

${ }^{72}$ UK Local Authority Food Law Enforcement Annual Report 2014/15 28 January 2016.
} 
GBP 22 million in savings while local authority environmental health budgets have been reduced by 20 per cent. ${ }^{73}$

\section{B. The EU Level}

The first, and in our view the most important, factor in the crisis was the Union's inability to deal with the fraudulent practices which lay at the heart of the horsemeat scandal. The EU's food control regime was simply not designed to deal with issues of food fraud as opposed to food safety. Indeed, it may be argued that EU food law actually supports, albeit unintentionally, food fraud, due to the manner in which free movement rules have been designed and applied. The UK Select Committee concluded that "there is every indication that horse meat has been intentionally substituted for beef by criminals with access to the food industry. Elements within the food industry have duped consumers in the UK and across Europe in pursuit of profit". ${ }^{74}$ The horsemeat was mislabelled as beef at some point between leaving the plants in Poland/Romania and arriving in the UK/Ireland. Although it remains unclear precisely where the adulteration occurred, it is likely to have taken place in situ at either a warehouse or processing plant, as adulteration simply cannot take place once the goods are in transit. Some of the horses were legitimately slaughtered in approved slaughterhouses which have a full time official presence but were subsequently sold to cutting plants with no such official presence. These cutting plants appear to be the weak link in the supply chain. Nevertheless, this was not considered a food safety issue, but rather an issue of fraudulent consumer misinformation. However, as the Chartered Institute for Environmental Health noted in its evidence to the UK Select Committee, although there were initially no health concerns "it seems improbable that individuals prepared to pass horse meat off as beef illegally are applying the high hygiene standards rightly required in the food production industry" ${ }^{75}$ Food authenticity is not the primary focus of RASFF and so it was not initially triggered. As we shall see, the Commission is currently in the process of developing a system, similar to RASFF, which will be dedicated to the prevention of food fraud.

Perhaps the most obvious-but understandable-weakness in the EU regulations is that although the Union legislates, enforcement is left to the Member States. As we have already seen, Member States often delegate responsibility for food safety enforcement to

\footnotetext{
73 J. Doward, "Food Checks 25\% down despite horsemeat crisis" The Guardian 30 January 2016.

${ }^{74}$ Environment, Food and Rural Affairs Committee - Eighth Report on Contamination of Beef Products, at para. 43.

${ }^{75}$ Ibid., at para. 21.
} 
local authorities who, at least in the UK, are facing severe budgetary restrictions. Not only does the multi-level structure of food safety regulation lead to weakened enforcement, but it also serves to discourage the reestablishment of institutional trust as "[n]otwithstanding European economic integration, consumer trust is primarily generated within a national context". ${ }^{76}$ A further complicating factor relating to the application of the General Food Law Regulation at national level was the lack of clarity surrounding the recall obligation contained in Article 19. In Ireland, where the scandal first came to light, some businesses voluntarily recalled products but the authorities did not mandate any such recall as "in the absence of concrete indication of food safety risks, the conditions of Article 19 (...) were not met, while national instruments were lacking" ${ }^{77}$ The German authorities adopted the same interpretation of Article 19 but were able to order a recall based on the wider scope of national law. ${ }^{78}$ At the other end of the spectrum, the Dutch, Greek and Portuguese authorities considered that a mere infringement of the Article 18 traceability requirements was enough to trigger the Article 19 recall obligation. It is clear that a preliminary reference to the CJEU is needed to resolve this issue and that "[s]uch fundamental differences in interpretation of core provisions of EU food law are not tenable in the long run". ${ }^{79}$ In addition, there has been growing pressure in recent years for meat inspection to be deregulated or even privatised. Meat inspectors currently working in abattoirs are mainly state-employed although the activities of official veterinarians are often outsourced. Criticisms of privatisation have centred on the fact that inspectors employed by the abattoirs might come under severe pressure from their employers to cut corners and save costs. ${ }^{80}$ Trade unions have been particularly vocal in their opposition to such moves and have recently been involved in industrial action to improve pay and working conditions for meat inspectors and official veterinarians. ${ }^{81}$

The second issue is the difficulty in tracing horses across the EU. The scale of unregulated horse breeding and trading in the UK has made horses entering the slaughtering

\footnotetext{
${ }^{76}$ C. Ansell and D. Vogel (eds), What's the Beef? - The Contested Governance of European Food Safety (Cambridge MA 2006) 20, 32.

${ }^{77}$ Van der Muelen and others, "Fighting Food Fraud, Horsemeat Scandal; Use of Recalls in Enforcement throughout the EU", p. 3.

${ }^{78}$ Ibid., at p. 13.

79 Ibid.

${ }^{80} \mathrm{See}$ in relation to poultry self-regulation and animal welfare $<$ www.theguardian.com/business/2016/mar/25/uk-poultry-deregulation-risk-food-scares-bse-foot-mouth > accessed 20 April 2016.

${ }^{81}$ See Unison, "Meat inspectors deserve fair pay" <www.unison.org.uk/our-campaigns/meat-inspectorsdeserve-fair-pay/> accessed 23 March 2016.
} 
chain "vulnerable to mislabelling and traceability problems". ${ }^{82}$ There is also a cultural issue: part of the problem was the fact that there is no taboo about eating horsemeat on the continent. Therefore, it would not be considered unusual to use horsemeat in beef products. In other words, for much of Continental Europe the question was: what scandal?

Beyond the food safety regime, what role was played by the EU's core rules on the free movement of goods? It seems that not only did the free movement of goods play a role in the rapid movement of the products and failure to identify the fraud, but the Court's interpretation of those rules made it even more difficult for the Member States to invoke the Article 36 health derogation. This point was emphasised by the Commissioner at a press conference on 13 February 2013. He cautioned countries against moving to ban imports, noting that even if bans were introduced in the event of a food safety issue, any bans would be temporary:

[1]et no one use this incident in order to undermine one of the greatest achievements of the European Union, the free movement of goods, including meat products throughout the European Union. ${ }^{83}$

The UK concurred. The Secretary of State said in the House of Commons, "unless there is a threat to public health and safety, there are no grounds for stopping imports. Fraudulent labelling and mislabelling are quite wrong, but he [Commissioner Borg] made it clear during our brief conversation, on which I hope to elaborate tomorrow, that those were not grounds for preventing the importation of a material within the European Union". ${ }^{4}$ Since the establishment of the Single Market it is certainly difficult for Member States to introduce import controls from within the EU. Each EU Member State is required to take responsibility for animal health, public health and food hygiene within their own country. The Commission's Food and Veterinary Office may carry out checks in all Member States to ensure food is produced in accordance with EU requirements and can impose sanctions. Otherwise, meat and other products of animal origin produced in the EU may be traded freely within the EU. Checks may be carried out at the border where there are grounds to suspect that the consignment does not comply with the EU conditions and checks may be undertaken by inland authorities to verify controls in the originating Member State. Such controls must

\footnotetext{
${ }^{82}$ Environment, Food and Rural Affairs Committee - Eighth Report on Contamination of Beef Products, at para. 13.

${ }^{83}$ S. Lynch, "European Commission abdicates responsibility for horse meat scandal" Irish Times 14 February 2013.

${ }^{84}$ Hansard, 12 February 2013 Column 741.
} 
of course respect the non-discrimination rule, i.e. EU law permits Member States to apply inland restrictive measures to goods originating from other Member States, as long as the measures are applied equally to domestic goods and do not go further than necessary. ${ }^{85}$

Furthermore, Regulation 178/2002 itself lays down that where it is evident that food originating in the EU is likely to constitute a serious risk to human health, animal health or the environment, and that such risk cannot be contained satisfactorily by means of measures taken by the Member State concerned, the Commission, acting on its own initiative or at the request of a Member State may suspend access to the market, lay down special conditions or adopt any other appropriate interim measure. In this respect, Article 53 of the Regulation is similar to the Article 36 TFEU. This puts the EU's ability to control the movement of potentially hazardous food on a surer footing. Earlier attempts at preventing free movement had been met with challenges from Member State authorities. In relation to the BSE crisis, the UK Government had sought the annulment of Commission Decision 96/239/EC on emergency measures to protect against BSE which included a prohibition on UK exports of certain animal products to the rest of the EU. One of the main arguments advanced by the UK Authorities was the infringement of the principle of the free movement of goods. In a reversal of roles, it was the Commission in the BSE case that sought to prevent free movement. The CJEU, finding for the Commission noted that "in order for such containment [of infected meat] to be effective, it may in some cases be necessary to impose a total ban on the movement of animals and products outside the frontiers of the Member State concerned" ${ }^{86}$ However, the limited ability of the Member States to impose import bans does not take away from the fact that there is a positive duty on the Member States to ensure that the EU's food safety rules are in fact enforced. As we have seen, this duty extents to taking offending goods off the Member State market.

It is perhaps going too far to say that EU rules were a direct cause of the problem, but it provided a fertile context in which the crisis could quickly take hold. Although, as already discussed, the literature emphasises the lack of trust between states, in reality there seems to have been too much trust between traders, middlemen and regulators. This point was noted by the UK Secretary of State, Owen Paterson, who said in the House of Commons, "the problem is a paper-based system. The problem is that there is too much faith-the certificate

\footnotetext{
${ }^{86}$ Case C-180/96 United Kingdom v Commission [1998] ECR I-2265, at para. 58.
} 
and manifest on the content of pallets is taken on trust and there is not enough testing of the material". 87

In a similar vein, the Irish investigation noted that reforms were needed: it said that while the movement of goods and trade within the Internal Market is facilitated by the use of commercial documents accompanying consignments, consideration should be given to the level of detail and consistency of such documents to facilitate better traceability. ${ }^{88}$ A further example illustrates this. The adulterated frozen beef products manufactured by Silvercrest in Monaghan, Ireland were labelled as being of Polish origin. The originating plant in Poland had EU approval. The fact that the plant had EU approval suggested that was enough. Similar confidence in the system can be detected in the remarks made by Martin McAdam, the owner of a County Monaghan company allegedly dealing in contaminated meat products. He denied he had knowledge of the horse meat: "I went there as an innocent trading broker looking to import meat". ${ }^{89}$ He knew little about the company with whom he worked. One interpretation of this was that free trade was the norm and that businesses placed blind trust in other EU companies on the presumption that they would be working to the same standards. This suggests that free movement has become an article of faith which should not be challenged.

The EU free movement rules also had a role to play in facilitating complex supply chains. The rules undoubtedly made it much easier to move meat across the EU and this provided a rich context in which a network of middlemen and traders could get involved. Indeed, the manner in which goods are produced and brokered means that suppliers do not always take possession of the products. As the Irish Report concluded, "the involvement of traders has been highlighted in so far as they are effectively part of the food chain, but in some instances [they] do not appear to be fulfilling the obligations of food business operators". 90

Unlike domestic (EU) products, food imports from countries outside the Union can be subject to checks by local and port health authorities at Member State ports to ensure they comply with EU food law. Imports to the EU of meat and other products of animal origin from outside the EU must be pre-notified and must enter a Member State at designated

\footnotetext{
${ }^{87}$ Hansard, 12 February 2013 Column 744.

${ }^{88}$ Department of Agriculture Report on the Investigation into Equine DNA and the Mislabelling of Processed Beef.

89 "I didn't see or handle horsemeat' says Monaghan meat broker" BBC News 8 February 2013.

${ }^{90}$ Department of Agriculture Report on the Investigation into Equine DNA and the Mislabelling of Processed Beef.
} 
Border Inspection Posts where they are subject to veterinary checks to ensure import conditions have been met. There are currently 250 to 300 Border Inspection Posts in the EU which carry out identity, physical and documentary checks on third country imports of meat and additional checks if fraud is suspected. All consignments are subject to documentary and identity checks and a prescribed percentage of consignments are subject to physical checks. ${ }^{91}$ If problems are found with Third Country products, information exchanges follow between the Member States (information on non-compliant products is shared through the TRACES the EU Commission Trade Control and Expert System) and the next ten consignments entering the EU from that Third Country or establishment are held at port while results are awaited. $^{92}$

In conclusion, we cannot say that the EU's food regulation regime or the rules in Article 34 TFEU were the cause of the horsemeat scandal. However, the emphasis on food safety simply made regulators blind to the extent of food fraud taking place across the Union. We can also say that the Single Market may have incentivised the fraud as those involved had access to a larger market. The price competition caused by the Internal Market also seems to have been an incentive to seek cheaper products in other Member States. The free movement of goods certainly seems to be a problem to the extent that once the goods are in the EU, blind faith is placed on the quality of the products. In this respect, it is perhaps more accurate to say that the EU rules, rather than exacerbating the fraud, simply amplified the extent to which it could occur.

\section{WHAT HAS BEEN DONE SINCE?}

\section{A. The Legislative Response}

So we have seen the genesis of the crisis and we have considered how the EU regime of free movement and food safety may have (unwittingly) provided the context and the incentives to facilitate the fraud. The question, then, is how has the EU legislature responded?

Already in the pipeline before the outbreak of the scandal, Regulation 1169/2011 was adopted following the crisis and contains a number of measures which directly relate to the

\footnotetext{
${ }^{91}$ D. Heath, Written Evidence to the Environment Committee (Volume II) Ev 19.

${ }^{92}$ FSA, Written Evidence to the Environment Committee (Volume II) Ev 29.
} 
issue of food fraud. ${ }^{93}$ This Regulation replaces and combines into one piece of legislation previous labelling rules. ${ }^{94}$ It introduces the mandatory display of nutritional information on processed foods and the mandatory origin labelling of unprocessed meat from pigs, sheep, goats and poultry. ${ }^{95}$ Article $26(3)$ provides that where the origin of a food is given and where this origin is not the same as that of its primary ingredient, the origin of the primary ingredient must also be provided or be indicated as being different from that of the food. ${ }^{96}$ The Regulation entered into effect on 13 December 2014 and is intended to ensure that consumers receive clearer, more comprehensive and accurate information on food content and can therefore make more informed choices about what they eat. The mandatory nutritional labelling for processed food will only apply from 13 December 2016. FBOs have been given three years to ensure a smooth transition towards the new labelling regime for pre-packed and non-pre-packed foods. In addition, the Regulation provides for the exhaustion of stocks of foods placed on the market or labelled before 13 December 2014. As of 1 April 2015, with some exemptions, the Member State or third country where the animal was reared and slaughtered will appear on the label of such meats. For foods bearing origin indications, the country of origin or place of provenance of the main ingredients must also be listed if those ingredients originate from a different place than the declared origin of the finished product.

According to the Commission, although food fraud can take various forms, such as adulteration or substitution, the new rules will ensure that when a food is not exactly what it appears to be, relevant information will be provided to prevent consumers from being misled by a certain presentation or appearance. When some ingredients, normally expected to be in the food, have been replaced by others, the substitute ingredients will be labelled prominently on the package and not only in the list of ingredients. For foods implying or indicating a false origin, the new rules set certain criteria to ensure that voluntary origin indications do not mislead consumers. Operators who make origin claims are required to provide further information so that people know where the characterising ingredient of the food actually comes from and not just the last country where the food was processed. ${ }^{97}$

\footnotetext{
93 Council and Parliament Regulation (EU) No 1169/2011 (OJ 2011 L 304 p. 18).

${ }^{94}$ Deriving from Directives 2000/13/ EC and 90/496/EEC (See above note 38).

95 Art 26(2)(b).

${ }^{96}$ Commission Implementing Regulation (EU) No 1337/2013 (OJ 2013 L 335 p. 19).

97 See European Commission, "Questions and Answers on Food Information to Consumers" $<$ http://europa.eu/rapid/press-release_MEMO-14-2561_en.htm> accessed 23 March 2016.
} 
Under Article 26(6) of the Regulation, the Commission was required to submit a report to the European Parliament and the Council concerning the possibility of extending mandatory origin labelling to meat used as an ingredient in pre-packed foods. The Commission presented this Report on 13 December 2013. ${ }^{98}$ The Report, which covered meat of all species used as an ingredient of pre-packed foods, notes that the supply chain of meat used as an ingredient is quite complex and lengthy, involving several steps in the production and marketing of the final products, with raw materials from several suppliers often being mixed into one product. ${ }^{99}$ Due to these complexities there was little appetite among processors to introduce mandatory origin labelling. ${ }^{100}$ It was further concluded that the EU's existing traceability systems were not adequate to pass on origin information along the food chain. This is because the existing legislation was, as already mentioned, based primarily on ensuring food safety. In addition, the more detailed traceability systems that do exist vary between animal species and do not extend beyond the unprocessed phase. ${ }^{101}$ The Report notes that consumer interest in origin labelling for meat ingredients is strong, although there were significant differences in attitudes and priorities between Member States. ${ }^{102}$ However, introducing any meaningful origin labelling (beyond EU/non-EU) would lead to significant extra costs. The Staff Working Document, which accompanies the Report, concludes that origin labelling for meat used as an ingredient could not be considered as a tool to prevent fraudulent practices. ${ }^{103}$ Nevertheless, on 15 January 2014, the European Parliament adopted a Resolution calling on the Commission to introduce mandatory labelling of the country of origin of meat used in processed foods as is already the case with fresh bovine meat. ${ }^{104}$ The intention behind this legislation would be to rebuild consumer confidence. MEPs were reacting to the Report of Dutch MEP Esther De Lange calling on the Commission to suggest new laws to prevent another scandal similar to the horsemeat scandal and to "improve traceability in the food chain by making meat labelling mandatory”. ${ }^{105}$

\footnotetext{
${ }^{98}$ Commission Report regarding the mandatory indication of the country of origin or place of provenance for meat used as an ingredient SWD (2013) 437 final.

99 Ibid., at p. 4.

${ }^{100}$ Ibid., at p. 5.

${ }^{101}$ Commission Implementing Regulation (EU) No 931/2011 (OJ 2011 L 242 p. 2).

${ }^{102}$ Commission Report regarding the mandatory indication of the country of origin or place of provenance for meat used as an ingredient, p. 13.

${ }^{103}$ Commission Staff Working Document of 17 December 2013 SWD (2013) 437 final.

${ }^{104}$ European Parliament Resolution of 11 February 2015 on country of origin labelling for meat in processed food (2014/2875(RSP)).

${ }^{105}$ Draft Report on the food crisis, fraud in the food chain and the control thereof of 8 October 2013 (2013/2091(INI)).
} 
Of course, origin labelling is not enough to counter another adulteration scandal and so, in addition to the above legislation, the Commission has also introduced new measures to enhance the EU control system as a whole. The intention is to improve the mechanisms for detecting and countering violations of EU food rules which are motivated by financial or economic benefits. One such measure is the creation of an EU Food Fraud Network comprising of Commission and EEA Member State representatives who will discuss how to strengthen coordination on cross-border fraud issues. The Member State contact points are the authorities designated to ensure cross-border administrative assistance and cooperation on matters that relate to economically motivated violations of food law requirements. It is intended that the Network will meet on a regular basis. Aside from these formal meetings the Member State contact points and the Commission will also be in permanent communication. Information will be exchanged in cases where the results of official controls in one Member State indicate possible violations of food law requirements. Further measures which have been adopted include the development of a dedicated Information Technology tool akin to RASFF to enable the rapid exchange of information on potential cross-border fraud, the better coordination at EU level of all services relating to food fraud and the establishment of a dedicated team within DG Health and Consumers. ${ }^{106}$ In addition, the Commission is expected to make proposals in the near future on improving the harmonisation of penalties and extending EU rules on food origin to include more food types. ${ }^{107}$

Finally, Regulation $882 / 2004$ on official controls is also under review. ${ }^{108}$ The Commission has proposed the introduction of sufficiently dissuasive financial penalties which should exceed the benefits of the fraud. Member States should include in their control plans regular, unannounced, official controls directed at combating fraud. The Commission can also impose-as opposed to merely recommend-coordinated testing programmes in specific cases.

\section{B. The Industry Response}

Given that food business operators bear the ultimate responsibility for ensuring the safety and authenticity of their food it is worth considering the industry response to the crisis. Large retailers, in particular, have always had a strong influence on the regulation and content of

\footnotetext{
${ }^{106}$ See European Commission, "What has the EU done so far to address the horse meat scandal?" $<$ http://ec.europa.eu/food/food/horsemeat/timeline_en.htm> accessed 23 March 2016.

${ }^{107}$ See <http://ec.europa.eu/news/agriculture/130311_en.htm> accessed 23 March 2016.

${ }^{108}$ Regulation 882/2004 (See above note 35 ).
} 
food safety standards. Indeed, the supply chains with different power allocations between retailers, traders and suppliers lead to differing contractual practices. Many suppliers are dependent on large retailers, granting those retailers particular power in ensuring standards and traceability. ${ }^{109}$ As such, the reaction of the retailers to the scandal was closely watched. The large supermarkets, in their evidence before the UK Select Committee, sought to emphasise that much of their food is now sourced from local (British and Irish) farmers and producers. ${ }^{110}$ David Heath remarked that people should be reassured that, "the vast majority of processed meat that was on sale was perfectly as it should be (...) I can only applaud the fact that people are tending to buy British meat products, which they know they can trust". 111

The UK Elliot Report noted that, "[i]ndustry must recognise that audits should be about ensuring a safe, high integrity supply chain that protects their business and their customers". ${ }^{112}$ This is beginning to happen: companies are changing their oversight procedures with their suppliers. Paul Finnerty of ABP said that the issue at Silvercrest Foods was that they had used suppliers that had not been approved by Tesco. As a response, ABP no longer buy from middle men but from primary sites and now seek to source frozen burgers from the UK and Ireland only. Finnerty also sought to emphasise the differences between frozen and non-frozen beef:

[f]or chilled beef (...) the supply chain is very short. We try to procure two-thirds of our cattle from within a 30 -mile radius of each of the facilities we use (...) It is a process that takes a matter of days and a short number of weeks. Frozen food is different. It is a product that has a lifespan of up to two years, and the raw material that is bought is much more commoditised (...) it tends to go through many hands. ${ }^{113}$

This suggests that the buy local approach has its limits. It remains the case that for frozen products, for example burgers, retailers will continue to rely on multiple suppliers given the vast range of component ingredients involved in their production. As the Elliot Report concluded:

\footnotetext{
${ }^{109}$ F. Cafaggi, "Private Regulation, Supply Chain and Contractual Networks: The Case of Food Safety" EUI Working Papers RSCAS 2010/10, 3.

${ }^{110}$ Environment, Food and Rural Affairs Committee - Eighth Report on Contamination of Beef Products.

111 Ibid., at p. 9.

${ }^{112}$ Elliott Review into the Integrity and Assurance of Food Supply Networks - Final Report A National Food Crime Prevention Framework July 2014, 2.

${ }^{113}$ Environment, Food and Rural Affairs Committee - Eighth Report on Contamination of Beef Products, at para. 24.
} 
[t]he current industry focus on developing shorter supply chains and on sourcing locally produced foods in long term partnerships is of enormous importance in terms of having a more resilient, higher integrity UK food system (...) However, we cannot escape the need to actively participate in global food supply systems and must develop a new mentality when sourcing from sometimes highly complex international markets. ${ }^{114}$

Given Tesco's high-profile involvement in the scandal their response was eagerly anticipated. In the immediate aftermath of the crisis, Tesco issued a widely publicised apology assuring its customers that it would find out what had gone wrong. After subsequent investigations the company concluded that the burger supplier was not on the list of approved suppliers nor was the meat from the UK or Ireland. Tesco promised to cut all links with the supplier in question and introduced a "comprehensive system of DNA testing across our meat products". Following this apology Tesco launched a "farm and factory" (now mostly aimed at children) website as part of its plans to open up its supply chains to customers. ${ }^{115}$ Chief Executive, Philip Clarke promised that "we will take you right the way into the farms and the factories. We'll allow you to see who the farmers are, how they produce for us [and] the care and attention that I know that they take". ${ }^{116}$ Tesco was awarded the 2013 CorpComm Prize for crisis management for its response to the scandal as it "showed grace under fire. It was clear on its objectives and it delivered". ${ }^{117}$ The company was, in particular, praised for its three simple promises of putting in place better controls, bringing food closer to home and building better relationships with the farmer.

Beyond industry self-congratulation, PR management, and CSR initiatives, Tesco has taken some concrete steps to prevent a future scandal. The company has introduced DNA testing checks to "set a new standard", created a new supplier list and reduced the number of abattoirs it uses. ${ }^{118}$ Tesco also announced that it is undertaking a "forensic" examination of its entire supply chain and will remove anyone in the chain who it does not believe is adding

\footnotetext{
${ }^{114}$ Elliott review into the integrity and assurance of food supply networks: final report 4 September 2014, 3.

115 Tesco, "Farm to Fork" <www.eathappyproject.com/farm-to-fork/> accessed 23 March 2016.

${ }^{116}$ B. Bold, "Tesco tackles horsemeat scandal with website showing food suppliers"

$<$ www.marketingmagazine.co.uk/article/1171099/tesco-tackles-horsemeat-scandal-website-showing-foodsuppliers> accessed 23 March 2016.

${ }^{117}$ R. Ford, "Tesco wins CorpComm award for horsemeat scandal response"

$<$ www.thegrocer.co.uk/home/latest-news/tesco-wins-corpcomms-award-for-horsemeat-scandalresponse/352991.article> accessed 23 March 2016.

${ }^{118}$ Trading Responsibly: Improving the Way We Serve Our Customers and Work With Our Suppliers, Tesco February 2014.
} 
value. ${ }^{119}$ This move reflects the need for a broader transition from transactional to relational supply chains with stability of suppliers recognised as an asset to be nurtured. Reliance on contractual sanctions alone is no longer tenable. It nonetheless remains the case that Tesco only examines its first tier suppliers (one level back) and that level subsequently examines the second tier. It is clear that a more robust system is required across the entire industry. Perhaps there are lessons to be drawn from the Modern Slavery Act which includes a provision for increased supply chain transparency. ${ }^{120}$ For now, it remains the case that the current multilevel supply chain depends on each level holding the next to account; this is an inherently reactive and unreliable approach.

Is there also a potential role of self-regulation or private regulation? Cafaggi notes that private regulation, notably regulation via networks of contracts, for example associated to traceability, may affect the form and function of the supply chain, requiring "specific contractual arrangements among suppliers and between them and retailers to implement the safety standards and to monitor their compliance". ${ }^{121}$ This approach was thought to be particularly useful for the surveillance of risk assessment and risk management strategies at transnational level. ${ }^{122}$ As Havinga has pointed out, sociological research shows that "often what is postulated in a contract is not what in fact happens. So including compliance with a food safety standard in the retailer's product specifications is not enough". ${ }^{123}$ Of course, private regulation is insufficient in itself and so new forms of co-regulation between the public and private spheres have been adopted. A notable development has been the emergence of a "supply chain" approach to ensuring food safety. This approach essentially involves the inclusion of the entire supply chain but especially retailers in monitoring the safety of products. It was precisely on this approach that the existing EU food safety regulation was based, largely as a result of earlier international food scares such as BSE and dioxin. $^{124}$

\section{Prosecutions}

\footnotetext{
119 “Tesco's Supply Chain Shake Up to Cut Out Middlemen, Farmers” The Guardian 26 May 2013.

${ }^{120}$ UK Government, "Transparency in Supply Chains etc. A practical guide" <www.gov.uk/government/uploads/system/uploads/attachment_data/file/471996/Transparency_in_Supply_Chai ns_etc_A_practical_guide_final_.pdf $>$ accessed 20 May 2016.

${ }^{121}$ Cafaggi, "Private Regulation, Supply Chain and Contractual Networks: The Case of Food Safety", p. 1.

122 Ibid.

${ }^{123}$ T. Havinga, "Private Regulation of Food Safety by Supermarkets" (2006) 28 Law \& Policy 515, 526.

${ }^{124}$ Cafaggi, "Private Regulation, Supply Chain and Contractual Networks: The Case of Food Safety", p. 2.
} 
In the aftermath of the scandal there were immediate calls for the perpetrators of the fraud to be brought to justice. In fact, little has come of such calls. There have been very few successful prosecutions resulting from the scandal and none at all in Ireland, although one is pending. ${ }^{125}$ What the prosecutions do show is that for many involved in the industry fraudulent practices were almost considered part and parcel of the ordinary course of business.

In the UK none of the prosecutions actually involved the deliberate mislabelling of foreign horsemeat as beef. It is, however, worth looking at the prosecutions brought against Peter Boddy and David Moss to gain an understanding of what was happening. They admitted to a number of charges indirectly relating to the horsemeat scandal. Boddy was convicted on two counts for failing to comply with food traceability requirements. Moss received a four-month prison sentence, suspended for two years, and Boddy was fined GBP 4,000 for each count. Boddy was the owner of a slaughterhouse in Todmorden, West Yorkshire which sold horse meat to customers (this was a legitimate part of his business). However, he sold 55 carcasses without keeping any record of where they were going and 37 of these he claimed went to Italian restaurants in the UK. A further 17 animals entered his business without documents showing where they had come from. There was, however, no proof the pair had deliberately tried to pass horsemeat off as beef. The judge noted that the two men were not being sentenced for any role they might have played in the fraudulent substitution of horsemeat for beef in the consumer market but said that:

[i]t is impossible to avoid a suspicion, even a strong one, that behind the activities disclosed by this investigation was some degree of complicity, together with others those who sold the live horses to the abattoir, and those who received the horse meat thereafter - in putting into the human food chain, under the guise of some other meat, what was in fact horse meat.

There were also a number of prosecutions brought in the Netherlands, including that of Jans Fasen, Director of Draap Trading (helpfully Draap is horse spelt backwards in Dutch). This Cypriot-registered company was run from Antwerp and owned by an offshore vehicle based

\footnotetext{
${ }^{125}$ Department of Agriculture Report on the Investigation into Equine DNA and the Mislabelling of Processed Beef.
} 
in the British Virgin Islands. ${ }^{126}$ On 8 April 2014, Fasen was arrested in Paris and admitted to buying a consignment of horsemeat from two Romanian abattoirs and selling it to French companies; he argued that it had been correctly labelled as horsemeat. ${ }^{127}$ It is alleged that Draap had received horsemeat from Romania and sold it in France as beef. Draap had delivered the meat to the French company Spanghero which in turn supplied Comigel, another French company. The Findus lasagne products in the UK, which were found to contain horse meat, had been obtained from the Comigel factory in Luxembourg. Spanghero maintained that the meat it had received from Draap was labelled as beef originating in the EU. The Romanian slaughterhouses (Doly Com and Carmolimp) which had supplied the meat to Draap denied mislabelling horsemeat as beef. Sorin Minea, head of Romalimenta, the Romanian food industry federation, told the Guardian: "[t]here is an international mafia ring behind this problem. I don't know who they may be, or whether any Romanians are involved. But if you think about it, there were five intermediaries so I'm sure that an international network is involved". ${ }^{128}$

The only Dutch conviction so far is that of horsemeat trader Willy Selten, the owner of Willy Selten BV based in the Netherlands. On 7 April 2015 Selten was found guilty of falsifying documents and jailed for two and a half years for his role in the horsemeat scandal. He had been arrested in May 2013 for selling 300 tonnes of horsemeat labelled as beef (the horsemeat had been sourced in the Netherlands, UK and Ireland in 2011 and 2012). He was found guilty of forging invoices, labels and declarations and using forged documents to sell meat. ${ }^{129} \mathrm{He}$ had been mixing horsemeat with beef and selling it as 100 percent beef. Prosecutors said the horsemeat was processed as beef at the company's headquarters in Oss. The Dutch Authorities had taken 167 samples from his meat supplies in February 2013 and 35 of these tested positive for horse DNA. Some 132 companies across Europe that purchased meat from Mr Selten have been ordered to trace it and remove it from sale if it has not yet been consumed.

\section{CONCLUSION}

\footnotetext{
${ }^{126}$ L. Harding and I. Traynor, "Horsemeat scandal: Dutch meat trader could be central figure" The Guardian 13 February 2013.

${ }^{127}$ See G. Guyton, "Dutch Trade Charged over Horsemeat Scandal" <www.globalmeatnews.com/IndustryMarkets/Dutch-business-charged-over-horse-meat-scandal> accessed 20 May 2015.

${ }^{128}$ Harding and Traynor, "Horsemeat scandal: Dutch meat trader could be central figure".

129 "Horsemeat scandal: Dutch trader found guilty and jailed" BBC News 7 April 2015.
} 
At the outset of this article we asked whether the EU's food safety regime or the Treaty provisions on free movement of goods were in any way responsible for the scandal. The Commission was adamant that they did not play a role. We disagree in part. The EU rules on free movement created an opportunity for unscrupulous operators to operate. Considerable faith was placed in the quality of products moving within the EU. Further, the Internal Market may have incentivised the fraud in that those involved had access to a larger market. The price war between supermarkets also seems to have been an incentive to seek cheaper products in other Member States. In addition, the regulatory regime at the time had been set up to respond to the last crisis, the BSE crisis, which concerned food safety not the longstanding and well known issue of food fraud. Indeed, in relation to earlier crises involving BSE and dioxin (the contamination of food products, mainly eggs and chickens in Belgium with polychlorinated biphenyls (PCB) and dioxin), "[i]t was a widely expressed concern at the time of the food scares [BSE and dioxin in the 1990s] that, as a result of economic globalisation and trade liberalisation, the EU would advance powerful industry interests at the expense of public health and consumer interests". ${ }^{130}$ The revised regulatory regime introduced in the wake of the scandal was never originally intended to deal with the issue of fraudulent adulteration. Although it is perhaps too early to tell, it is difficult to escape the conclusion that the new scheme will ultimately fail to prevent fraud on the scale that occurred during the horsemeat scandal. It is now clear that although EU free movement rules may contribute to creating the problem, EU food law does not adequately address it due to the continued over-emphasis on safety as opposed to fraud.

There have already been reports of emerging fish adulteration scandals. ${ }^{131}$ Complex supply chains are simply here to stay particularly in relation to frozen or processed meat products which of necessity involve multiple suppliers. The reality is that only a multidimensional strategy is suitable for combating fraud. At EU level this would require a greater emphasis on the regulation of food fraud as opposed to just food safety, including the strengthening of traceability requirements. At national level the penalties need to be serious and backed up by a well-resourced enforcement strategy. Not only that, but Member State

\footnotetext{
${ }^{130}$ M. Dreyer and O. Renn, "EFSA Stakeholder and Public Involvement Policy and Practice: A Risk Governance Perspective" in A. Alemanno and S. Gabbi (eds), Foundations of EU Food Law and Policy (Farnham 2014), 171, 174.

${ }^{131}$ See $<$ http://ec.europa.eu/dgs/health_food-safety/dyna/enews/enews.cfm?al_id=1652> accessed 20 April 2016.
} 
authorities must begin to think and act "European". ${ }^{132}$ The proper functioning of the Internal Market cannot be wholly arranged from Brussels but rather depends on the continued assessment and reassessment of the appropriate division of powers between the Member States and the Union. Unfortunately, to date this issue has only ever been discussed in earnest at the time of Treaty revision. ${ }^{133}$ Without such an approach, the broader difficulties in the proper functioning of the Internal Market (in the food sector and beyond) will remain unresolved. Companies too have a role to play by shortening their supply chains and knowing who is doing what at all levels. It might have been thought that reputational risks would incentivise companies to put these measures into force ${ }^{134}$ but so long as there is a public demand for cheap food, corners are likely to be cut. Of course those committing fraud are also learning from the scandal and the response to it. Regulating for the last crisis may no longer be an option in the face of increasingly sophisticated criminal activity.

\footnotetext{
${ }^{132}$ Janssens, The Principle of Mutual Recognition in EU Law, p. 107; J. Pelkmans, "What strategy for a genuine single market?” CEPS Special Report No. 126/January 2016, 14.

133 Ibid.

${ }^{134}$ Findus have also rebranded since the scandal as it could not recover from the reputational damage, see $<$ www.telegraph.co.uk/news/shopping-and-consumer-news/12132995/Findus-Crispy-Pancakes-to-disappearfrom-frozen-food-aisles-after-50-years.html.> accessed 20 May 2015.
} 